UDC 930(477):912.43

DOI: $10.24919 / 2519-058 x .11 .170715$

\title{
Ivan KUTSYI
}

PhD hab. (History), Associate Professor of History of Ukraine, archeology and special branch of Historical Science Department of Ternopil Volodymyr Hnatiuk National Pedagogical University, 2 Maxyma Kryvonosa Street, Ternopil, Ukraine, postal code 46027

ORCID: https://orcid.org/0000-0002-3556-1962

ResearcherID: H-4431-2017 (http://www.researcherid.com/rid/H-4431-2017)

\section{Larysa KUTSA}

PhD (Philology), Lecturer of Department of philological disciplines of elementary education of Ternopil Volodymyr Hnatiuk National Pedagogical University, 2 Maxyma Kryvonosa Street, Ternopil, Ukraine, postal code 46027 (larkutsa@ukr.net)

ORCID: https://orcid.org/0000-0003-4877-9626

ResearcherID: J-2602-2018 (http://www.researcherid.com/rid/J-2602-2018)

\section{Іван КУЦИЙ}

доктор історичних наук, доиент кафедри історії Украӥни, археологї та спеціальних галузей історичної науки Тернопільського національного педагогічного університету імені Володимира Гнатюка, вул. М. Кривоноса, 2, м. Тернопіль, індекс 46027 (kutsyy@ukr.net)

\section{Лариса КУЦА}

кандидат філологічних наук, викладач кафедри філологічних дисциплін початкової освіти Тернопільського начіонального педагогічного університету імені Володимира Гнатюка, вул. М. Кривоноса, 2, м. Тернопіль, Україна, індекс 46027 (larkutsa@ukr.net)

Бібліографічний опис статті: Kutsyi, I. \& Kutsa, L. (2019). The images of the «East» in Ukrainian historiographic tradition: the problem of mental maps designing. Skhidnoievropeiskyi Istorychnyi Visnyk [East European Historical Bulletin], 11, 180-189. doi: 10.24919/2519-058x.11.170715

\section{IMAGES OF THE «EAST»IN UKRAINIAN HISTORIOGRAPHIC TRADITION: THE PROBLEM OF MENTAL MAPS DESIGNING}

Summary. The purpose of the research is to study the genesis concept of the "East» as the manifestation form of the spatial and the civilizational representations in the Ukrainian historiography, keeping track on the evolution of the historians' point of views concerning the Ukrainian position in relation to the diverse images of the "East», elucidating the concept correlation between the East and Asia, the West concept in Ukrainian historical thought, the analysis of the concept content of the East in historical texts. The methodology of the research is based on the mental maps as the cognitive reflection means of the geographic and spatial entities in the intellectuals' consciousness. The significant component of the methodological basis of the study is also the imagelogy as the strategy of looking into the images of «own» and «alien». The deconstruction of Orientalism (a specific way of perceiving and describing the concept of the East by the Western «intellectual thought» representatives), carried out in 
the researches of E. Said and L. Vulf, also serves the theoretical basis of the article. The scientific novelty of the research is based on the fact that the article is the first attempt of a special historiographical reflection on the specifics of the concept «East» usage in the Ukrainian historiographical tradition of the XIXth - XXth centuries. The conclusions are as follows: the several images of the concept of the «East» coexisted in the Ukrainian historical texts: the Slavic East, the Orthodox East, the Byzantine East, the Muslim East, the Turkic-Nomadic (Steppe) East. Some of these concepts convey the similar meaning and could be partially interchangeable, while the others are completely mutually exclusive. Numerous images of the East were differently identified by the Ukrainian historians according to the imagelogy evaluation formulae of «own» and «alien». If the Slavic East of the Orthodox East were perceived as "own», while the Muslim East and the Nomadic East were clearly construed and interpreted as «alien» or «hostile». Such kind of images of the East were marked in the historical texts as Asia. The Ukrainian historical thought has evolved from the complete inclusion (or exclusion) of the national-historical image of Ukraine to one of the Easts content (the XIXth - first quarter of the XXth century) to the spatial and civilizational identification formula, in which Ukraine combines the elements of the East (or several Easts) and the West. The above-mentioned idea is depicted in the popular historiographical formula "Ukraine between the East and the West».

Key words: East, West, Asia, civilization, image, identity, historiography.

\section{ОБРАЗИ «СХОДУ» В УКРАЇНСЬКІЙ ІСТОРІОГРАФІЧНІЙ ТРАДИЦІЇ: ПРОБЛЕМА КОНСТРУЮВАННЯ МЕНТАЛЬНИХ МАП}

Анотація. Метою статті є дослідження тенези концепту Схід як форми вияву просторових та иивілізаиійних уявлень в українській історіографії, простеження еволюиї̈ поглядів істориків на місие Украйни стосовно різних образів Сходу, з'ясування співвідношення понять Схід та Азія, Захід в українській історичній думиі, аналіз змістового наповнення поняття Схід в історичних текстах. Методологія дослідження базується на ментальних картах як способі когнітивного відображення географічно-просторових утворень у свідомості інтелектуалів. Вагомим компонентом методологічної бази дослідження є також імагологія як стратегія дослідження образів «свого-чужого». Теоретичною підставою статті виступає деконструкиія орієнталізму (специфічного способу сприйняття та описування Сходу представниками «західної» інтелектуальної думки), здійснена у студіях Е. Саїда та Л. Вулфа. Наукова новизна дослідження базується на тому, що стаття є першою спробою спеціальної історіографічної рефлексї̈ стосовно специфіки вживання конщепту «Схід» в украйнській історіографічній традичї XIX $-X X \mathrm{~cm}$. Висновки статті полягають насамперед у тому, що в українських історичних текстах співіснувало декілька образів Сходу: слов'янський Схід, православний Схід, візантійський Схід, мусульманський Схід, тюрксько-кочовий (степовий) Схід тощо. У змістовому наповненні цих понять окремі із них могли частково накладатись, а інші - повністю взаємовиключали один одного. Різні образи Сходу по-різному ідентифікувались украӥнськими істориками за імагологічною очінною формулою «свійчужсий». Якщо слов'янський Схід чи православний Схід сприймались як «свій», то мусульманський Схід та кочовий Схід однозначно трактувались як «чужий» чи «ворожий». Такі образи Сходу в історичних текстах маркувались також як Азія. Українська історична думка пройшла еволюиію від повного включення (або виключення) національно-історичного образу України до змісту одного із Сходів (XIX - периа чверть XX cm.) до формули просторової та циивілізаційної ідентифікаиії, за якою Украӥна поєднує елементи Сходу (або кількох Сходів) $i$ Заходу. Ця думка відображена у популярній історіографічній формулі «Украйна між Сходом та Заходом».

Ключові слова: Схід, Захід, Азія, цивілізаиія, образ, ідентичність, історіографія.

Problem statement. During the last decade in the Ukrainian historic science there gained popularity the problem of the Ukrainian inclusion in the supranational images of the West/ the East. Having passed through the stage of the «seeking state» in 1990-ies, the Ukrainian historical science intensified the search of Ukraine's place in the system of spatial, cultural, geopolitical and civilizational coordinates and images. Proceeding from the growing research dynamics of the above-mentioned problem, its obvious complexity, we consider the urgent 
necessity to specify and generalize the modern approaches in the process of studying the spatial and the civilizational images of the East. Although, the article is devoted to the study of the East images genesis, primarily, in the Ukrainian historiography of the XXth - the beginning of the XXIst century, we also turn to the corresponding interpretations of those foreign scientists whose works and views have had the significant influence on the Ukrainian intellectual space.

The analysis of sources and recent researches. If in 1991 Ya. Dashkevych, the researcher, historian, claimed about the problem of the Great Border (the boundaries between the European and the Eastern civilizations) as «controversial, but little discussed» (Dashkevych, 1991, p. 28), there has been an increase in the Ukrainian scientific interest (sometimes even the specific intellectual fashion) concerning the thematic complex of «Ukraine between the East and the West» during the last decade. According to Y. Hrytsak's observation, it is hard to come across the decent historian, who hasn't omitted the following topic at least once in Ukraine (Hrytsak, 2011, p. 291). The above-mentioned topic is often articulated as the applied or the theoretical research problem, but it has not become the subject of a special historiographical analysis yet.

The publication's purpose. The topicality of the outlined problem and the presence of the significant Ukrainian researchers' achievements in the field of the above-mentioned problem, instigates us to carry out the historiographical reflection on the process of the East images genesis in the Ukrainian historical thought of the XIXth - XXth centuries.

Statement of the basic material. The Concept of the East (as well as its opposition - the West) appeared to be one of the basic foundations of the mental maps of the scientists in the era of the Enlightenment before that time dominated the idea within the framework of the dichotomous opposition the North - the South (Kolesnyk, 2012, p. 148). At the same time, the East was regarded as the objectively existing (real), internally integral, homogeneous spatial unit. However, the historian E. Said in his work «Orientalism» proved in order to find their opposite feature («the other») and thereby reveal their own (the «Western») identity. According to V. Hrybovskyi, «the apparent self-identity of the East and the West», shattered after the Said's definition of the «Orientalism» (Hrybovskyi, 2010/2011, p. 511). L. Vulf's well-known arguments, with the help of which the principle of «difference» the Western European intellectuals «invented» the concept of the Eastern Europe as an image of the «another» Europe: «semi-Europe» or «semi-Asia» in the Enlightenment. Owing to the above-mentioned authors, the concept of the East began to be perceived not as a real integrity, but rather as an intellectual construct to a large extent. B. Anderson's concept of the «imagined community», i. e., the community of people whose members are not familiar with each other but they belong to it on the basis of a sense of belonging was relevant for the characteristics of the East (Anderson, 2001, p. 22). The binary opposition of «the East - the West» refers to one of the most important components in the mental maps of Ukrainian modernist intellectuals. This opposition includes the philosophical, the religious, the geospatial, the geopolitical, the historical, the social and the cultural meanings. According to many culturologists, this conditional (imaginary) semantic construct is created by the cultural thought for the world culture typology and expresses the dichotomy and the distinction between different models of the cultural identity; it expresses the dialectic of unity and plurality of the world culture as a complex dynamic integrity (Kondakov, Sokolov \& Khrenov, 2011, p. 334-335). S. Huntington, the author of the «clash of civilizations» concept construes the following dichotomy as the cultural division, which is based on the 
differences in defining the philosophical principles, the system of the values and the lifestyle (Huntington, 2006, p. 26).

According to Y. Hrytsak, the researcher, the historical and cultural identification in the coordinates of the «East - West» was the cross-cutting theme of the Ukrainian intelligentsia from the beginning of the modern era: «In 1830 - 1840-ies the Rus» Trinity figures argued about this issue; the Ukrainian modernists and modernizers generation on the verge of the XIXth and the XXth centuries focused on this issue; during the first post-war years it became one of the main topics of discussions» (Hrytsak, 2004, p. 296). L. Okinshevych claims that the issue of Ukraine's membership of the East or the West is the most significant, a nodule in Ukrainian history; all other issues depend on their solution (Okinshevych, 2011, p. 193). I. Kolesnyk assumes that the East / West dichotomy in the Ukrainian case cannot be explained only by one group of the reasons - the geopolitical, the economic, the cultural historical, etc. According to the researcher, this problem can be described with the help of the concept of biculturalism (Kolesnyk, 2013, p. 94).

It is quite obvious that both, in Ukrainian, as well as in the European intellectual traditions, such concepts as the East, Asia are not neutral, but they carry out a definite emotional estimation load. According to common stereotypes, the East or Asia (more often including Russia) appear to be the embodiments of such features as despotism, barbarism, collectivism, etc. As claimed by O. Hnatiuk, the Ukrainian debates on the national identity are closely linked to the dichotomy of the East - the West, or its more ideological option - Europe and Russia (Hnatiuk, 2005, p. 66). The Ukrainian historians formed their own autostereotype, and at the same time they carried out the «difference of the other» communities by attributing the following clichés: the eastern / the western, the European / the Asian. Hence, V. Hrybovskyi's opinion is appropriate, as the researcher offers «the consideration of geography as a text, and the geographical concepts as the constructs that fill it and, contrary to the attempts of scientisation, absorb the non-scientific images» (Hrybovskyi, 2010/2011, p. 513).

The dichotomy of the spatial delimitation on the East and the West was first observed in the era of antiquity. In particular, Herodotus interpreted the Greek-Persian War of the Vth century as the conflict between the East and the West. I. Shevchenko correlates the inclusion of these concepts in the spatial representation of the late antiquity with the division of the late Roman Empire into the eastern and western parts (Shevchenko, 2001, p. 2). According to the researcher, the explicit antagonism between these spatial entities is associated with the church division of the XIth century and the attack of the Crusaders on Byzantine in 1204. The medieval mental maps divided the area along the South-North, and only during the Enlightenment the spatial formula of the East-West returned. Numerous scientists have found the evidences of the contrast between the East and the West in the works of S. Montesquieu, F. Bernier, and G. W. F. Hegel. The intellectuals of the Modern age generally distinguished between the «western» (the private property and civil law with a limited role of the state) and the «eastern» (the leading role of the state apparatus in all spheres of the society life), the ways of historical development of the preindustrial societies (Krymskyi \& Pavlenko, 2007, p. 115).

As claimed by I. Shevchenko, in the two-division into the East - the West the Ukrainians «became the «East» in Western European eyes rather early - even before the division of Poland. This happened not only because most Ukrainians professed the «Eastern faith» ... / ... / The Polish-Lithuanian state was considered to be the part of the West in the XVIth century, but from the middle of the XVIIth century and almost until the middle of the XVIIIth century the West started unreasonably regarding this part to the East» (Shevchenko, 2001, p. 4-5). 
In the Ukrainian historical thought, the images of the East or Asia appear in the form of holistic, monolithic, timeless unities, which have their distinct socio-cultural identity. Let us, first of all, focus on the question of the ambiguity and the multiple interdependence of the interpretation of these concepts in Ukrainian historical texts. The opinion of many Ukrainian historians about the identity of the East with Russia is quite common, stereotyped. Thus, Lviv researcher S. Kost in the article «Between East and West», although acknowledging that «the East needs to be understood more broadly», nevertheless, substantially fills this concept with the Russian component (Kost, 2004, p. 260). It is hard to disagree with O. Hnatiuk's opinion, that in the European discourse of identity, Russia occupies a place of «another», which «is being withdrawn from the realm of «Europeanism» in the various ways. The definition of «Asian» with a negative connotation is endowed with the beginning of the XVIth century» (Hnatiuk, 2005, p. 78). In the Ukrainian historical thought, Russia was perceived as representing the two main ways of the civilization identity (the Slavic and the European ones) as the antipode of Europe or the West in the vast majority. However, if the European identity bearers often referred Russia to the part of the holistic East (or Asia), the Slavic identity representatives interpreted it only as the part of the «Slavic» (or «Orthodox») East and opposed it to another «Asian East» - the steppe nomads and the Muslim world.

L. Okinshevych identifies the East with the Eastern European Orthodox space, that is, the range of Byzantine cultural tradition. I. Lysiak-Rudnytsky mentioned that the concept of the East (or the Orient) is used by the Ukrainian historians for two totally different historical objects: «on the one hand, to the Eastern Christianity world and the Byzantine cultural tradition, on the other hand, to the Eurasian nomads world» (Lysiak-Rudnytskyi, 1994, p. 3). The historian argued that these two meanings of the concept of the East are quite different and from both sides the influence on the Ukrainian historical process was carried out in a completely different way.

The researcher Ya. Dashkevych put an emphasize on the practice of balancing «between the Euro- and Moscow-centricism resulted in the fact that the Ukrainian humanitarian sciences confused the parts of the world. Therefore, for the Ukrainian historians, the East is often associated with Byzantine or Moskoviya (a clear transposition of the Eurocentric stereotype for the Ukrainians), the North and the South are absent» (Dashkevych, 1991, p. 30). Actually the East, was denoted by this historian as follows: «the cultures spread territory and the Asian civilization», that is, everything that is located to the east and the south - east of Ukraine. The scientist even used the expression «true Orient», which emphasizes the author's conviction in the objective reality of such an education.

I. Shevchenko, determining generally the conditionality and the historical variability of the concept of the East, speaks mainly about the Byzantine East. Concerning Byzantine, the scientist notices that it «lies not to the east, but to the south - or even to the southwest - from Kyiv. It turns out that, bearing in mind the influence of Byzantium on Ukraine, we must speak not about the influence of the East, but part of the Mediterranean civilization» (Shevchenko, 2001, p. 1). I. Shevchenko traces that the concept «East» in the Eastern European folklore has a positive connotation inherited from the late antiquity of paganism, which was preserved in early Christianity.

The other researcher N. Yakovenko distinguishes in the Ukrainian historical imagination three completely different life-spatial images of the East: the Byzantine East, the Russian East and the Turkic East. Each of these «Easts» has left in Ukrainian history the «vivid tracks, which were mixed with each other intricately, and as well as with replicas of «the 
West» (Yakovenko, 2002, p. 363-364). According to an appropriate researcher's observation, the concept of the East has gradually «overgrown» with the ideological, the cultural, the spatial semantics in the Ukrainian historiography.

The situation with the use of the concept of Asia is equally ambiguous and controversial as in the case of the East. In general, it has the same semantic connotations as the East. However, L. Vulf warns that «despite all its fierce Orientalism, the Enlightenment has by no means unanimously equated the Asian continent with barbarism» (Vulf, 2009, p. 497). According to our observation, the Ukrainian historians associated all the countries or people of the Muslim world, as well as the nomadic (the Iranian and the Turkic) tribes, the nations and the states with Asia. The European civilization orientation representatives, in addition to it, included also Russia in the content of the concept of Asia, which often appeared in their historical texts as the main representative of the «Asian». For the Slavic civilizational identity bearers, Russia as the component (or even the core) of the Slavic world, of course, was as outside of Asia.

In the socio-cultural notion of Asia, the most controversial situation was with Byzantine. Thus, during the «long XIXth century» the thesis of Byzantine as a completely separate and independent civilization in Ukrainian historical thought can be traced rather poorly. If the Slavic and the European orientations historians recognized Byzantine as the part of the East (that is, as the antipode of the Latin - Catholic West), it is difficult to come across the idea of Byzantine belonging to Asia in their works. In the same way, with a different degree of clarity, the idea of the civilization (primarily the church - religious, as well as the political) between Byzantine and the Slavic world can be found. The identification of Byzantine with Asia took place more in the spatial-geographical sense. Hence, the contradictory nature of the Byzantine image in the civilizational representations of the Ukrainian historians was that this empire and civilization were clearly marked as «eastern», but with great difficulty «fitted» into the image of Asia. Therefore, the East and Asia appear in the civilizational representations of the Ukrainian historians not entirely identical to the concepts: if the East could be Byzantine, the Russian (or the Slavic), the Turkic, the Muslim, the nomadic (steppe), then Asia could be represented by the steppe nomads, the Muslim world, Russia (or one of the currents), but in most cases not Byzantine.

Consequently, the concepts of the East and Asia could be described by the Ukrainian historians as the holistic and intrinsically homogeneous entity (that is, as a synonym for any of the local civilizations), as well as for the super-civilization (or poly-civilization) spatial entities that include several images of the civilizations. The notion of the East and Asia often appear in the Ukrainian historical thought as forms of the manifestation of the civilizational identity. However, in many cases, their application is the manifestation of the spatial representations of the largest scale and the highest level of identity, which can be given the terms as supra-civilizational, macro regional. The problem with this level of identification lies in the fact that in some historians these concepts were identified with the image of only one civilization (for example, «the East = Russia» or «the East = the Muslim world»), while the other authors could include several civilizational images in the content of these concepts («the East $=$ Russia + the Muslim world + the nomadic steppe»).

In modern Ukraine, one of the most important signs of the normative historiography has become the European integration paradigm, which envisages the justification of the «Western» or «European» civilization, the cultural, the political identity of Ukraine and the interpretation of its historical past as the part of the European historical process. 
According to V. Honcharevskyi, the idea of the European identity of Ukraine today claims to be in the role of the newest national historical myth (Honcharevskyi, 2011, p. 151). It is clear that under such circumstances, for many Ukrainian historians, the desire to separate civilizationally at any cost, both from the former Soviet Union and from the present-day Russia, is noticeable. Nevertheless, there are still numerous attempts to position Ukraine with the East historiographically, namely, the component of the civilizations that are socio-cultural coincide with Russia. First of all, we refer here to the assertion that Ukraine belongs to such civilizations as: the Slavic, the Eastern Slavic, the Orthodox, the Eurasian, Byzantine, the Russian, Rus (Kyivska Rus as an independent civilization), etc. Of course, this reflects the significant influence of Russian historical thought. However, even in such interpretations of the Ukrainian scholars, Ukraine (and not Russia) appears to be the «Orthodox-Slavic» East civilization center. The following circumstance gives grounds for asserting that the Ukrainian civilization idea is not deprived of originality.

According to the observation of the culturologists, the semantic pair «the East - the West» has the character of the socio-cultural and the civilizational dilemma «either-or». Pretty common (or even stereotyped) are the idea of the mutually exclusive content of each of these images. However, modern Ukrainian historians (Y. Hrytsak, O. Tolochko) debunk the «civilizational myths» and prove that the traditional division into the «East» and the «West» cannot be a «serious helper tool» in modern history. As claimed by I. Shevchenko, the Ukrainian historians «paid much attention to the East-West axis, from which the cultural development of Ukraine depends on today, which is relatively small to the North-South axis / ... on this axis lies Moscow, Byzantine and its successor, Ottoman Empire» (Shevchenko, 2001, p. 8). This researcher in the discussion of the «eastern» / «western» nature of Ukrainian culture put an emphasize on another important circumstance - the lack of the direct access and, accordingly, the indirect influence of both the «eastern» and the «western» factors on Ukrainian cultural and historical processes .

It is vital to highlight that the Ukrainian historians of the late XVIIIth and early XXth centuries determined their spatial and civilizational identity by fully integrating their ethnonational space (Rus-Ukraine) into one of the civilizational images, which automatically meant a complete «exclusion» and the opposition to the image of «another» civilization. In other words, the identification was carried out according to the scheme: Rus-Ukraine is either the East, or the West, or the Slavic region, or Europe.

From the beginning of 1920-ies, we see a gradual abandonment of the established method of the civilizational self-identification, that is, the complete identification of oneself with the East or the West. At this time, according to N. Yakovenko's observation, the binary opposition of the East - West gradually began to transform into the thesis of a certain metaphysical triangle within which the territory of Ukraine is located. The main sides of this triangle are the «East» (Step), the «West» (Poland) and the «North» (Russia) (Yakovenko, 2002, p. 334-335). The thesis about the Ukrainian livelihoods in the form of a triangle is presented in the works of M. Hrushevskyi's Lviv students, in particular, S. Tomashivskyi. Regarding the M. Hrushevskyi's civilizational representations, V. Telvak evaluated them as ambivalent: the declared pro-Western historian was combined with «the historical accusation of the West in the destruction of the identity of Ukrainian culture» (Telvak, 2013, p. 302). In 1925 V. Lypynskyi brought in the formula «Ukraine between the East and the West», which according to M. Masnenko, became the concept of a peculiar «third way» in the civilizational landmarks between the West and the East and the variety of the Ukrainian messianic idea 
(Masnenko, 2013, p. 322). The above-mentioned concept was actively implemented in the Ukrainian historiography of the XXth century and remains popular in the intellectual circles up till the present day. According to A. Atamanenko, the recipients of the formula «Ukraine between the East and the West» (B. Krupnytskyi, I. Mirchuk, V. Yanov, I. Lisyak-Rudnytskyi, I. Shevchenko, etc.) adopted the idea of synthesis in the eastern (Byzantine) and the western (European) cultures. At the same time, the researchers emphasized the European membership of Ukraine - not only the geographic but also the cultural (Atamanenko, 2013, p. 377).

If during the «long XIXth century» the East and West were conceptualized as a completely self-sufficient and isolated living space, then in the interwar decades the formula of the civilizational identity presupposed the openness of Ukraine in regard to the external civilizational influences. That's why, Y. Hrytsak notes the following: «It will not be able to conceptualize Ukraine purely in the categories «either - or» - there is always a minimal possibility of the compromise formula «and - and «. / ... / In the dispute between two views, «either - or» the truth lies somewhere in the middle, that is, in the space «and - and» (Hrytsak, 2011, p. 294). L. Okinshevych justified the thesis that «Ukraine laid in the space of the two civilizations collision and was transitional type territory, we will never find a $100 \%$ admission of any of its parts to a particular cultural complex. The Western Ukraine has never been $100 \%$ Western and the Eastern Ukraine - 100\% Eastern Europe» (Okinshevych, 2011, p. 193).

Conclusions. In Ukrainian historical texts, several images of the East coexisted: the the Slavic East, the Orthodox East, the Byzantine East, the Muslim East, the Turkic-nomadic (steppe) East and the others. Some of these concepts convey the similar meaning and could be partially interchangeable, while the others are completely mutually exclusive. Numerous images of the East were differently identified by the Ukrainian historians according to the imagelogy evaluation formulae of «own» and «alien». If the Slavic East of the Orthodox East were perceived as «own», while the Muslim East and the Nomadic East were clearly construed and interpreted as «alien» or «hostile». Such kind of images of the East were marked in the historical texts as Asia. The Ukrainian historical thought has evolved from the complete inclusion (or exclusion) of the national-historical image of Ukraine to one of the Easts content (the XIXth - first quarter of the XXth century) to the spatial and civilizational identification formula, in which Ukraine combines the elements of the East (or several Easts) and the West. The abovementioned idea is depicted in the popular historiographical formula «Ukraine between the East and the West». On the mental maps of Ukrainian historians of the modern age, Russia was usually incorporated into one of the images of the East - mostly the Slavic or the Orthodox, but sometimes even the Turkic - «Asian». The concept of the «East» in the Ukrainian historiographical tradition functioned not only as a neutral working term for indicating a certain space or cultural-civilizational community. The usage of this term in the historical texts often carried out a certain emotional and estimated load: «lower», «backwardness», «uncivilized», «savagery» or some other (mostly negative) connotations. The European-centered ideological foundations had significantly influenced on the emotionally-biased and evaluative-negative attitude of Ukrainian historians to different images of the East by Ukrainian scholars, which has been especially evident in the recent decades in the European integration paradigm of the Ukrainian humanities. Hence, it could be argued that the modern Ukrainian historiography is characterized by a somewhat original form of the Orientalism as a specifically biased way of representing the Western intellectuals about the East as a space of the «backwardness», the "savagery», the «barbarism» and the «Asian threat». The Ukrainian historians also interpreted the East as 
an intellectual construct (or imagined community) in order to refer to the spatial images and the civilizational representations, and as a real spatial and cultural-civilization integrity. The topical task for the Ukrainian scholars is a detailed scientific explanation of how these spatial and civilizational images were part of the scientific representations and the historical consciousness of the Ukrainian historians, more precisely - as the Ukrainian historians «invented» and «imagined» the East and Asia in all their varieties. The detailed examination of the process of «fitting» Ukraine into the images of the East and the West at all stages of the Ukrainian historiographical process is also of the utmost importance.

Acknowledgements. The authors express their sincere gratitude to all participants of the international research project «History. Mentality. Similarity» for the sake of fruitful longterm cooperation, in which they received numerous constructive remarks, useful pieces of advice and fruitful discussions that were taken into account while writing the article. The proposed article partially reflects the results of the doctoral dissertation study. The authors are grateful to the leadership and all those involved in the doctoral program to the staff and scientists of Ternopil V. Hnatiuk National Pedagogical University and B. Khmelnytskyi National University of Cherkasy.

Funding. The authors did not receive any financial assistance for the research and publication of this scientific work.

\section{REFERENCES}

Anderson, B. (2001). Uiavleni spilnoty. Mirkuvannia shchodo pokhodzhennia i poshyrennia natsionalizmu [Imagined Communities: Reflections on the Origin and Spread of Nationalism]. Kyiv: Krytyka, 272 p. [in Ukrainian].

Atamanenko, A. (2013). Kontseptsiia Ukraina mizh Skhodom i Zakhodom u doslidzhenniakh chleniv Ukrainskoho Istorychnoho Tovarystva $\mathrm{z}$ davnoi istorii Ukrainy [The Concept of Ukraine between the East and theWest in the researches of members of the Ukrainian Historical Society of Ancient History of Ukraine]. Historia - Mentalność - Tożsamość. Rosja i Europa Zachodnia w polskiej i ukraińskiej historiografii XIX i XX wieku. (pp. 374-392). Gdańsk: Wydawnictwo Uniwersytetu Gdańskiego [in Ukrainian].

Vulf, L. (2009). Vynaidennia Skhidnoi Evropy: Mapa tsyvilizatsii u svidomosti epohy Prosvitnytstva [Inventing Eastern Europe: The Map of Civilization on the Mind of the Enlightenment]. Kyiv: Krytyka, 592 p. [in Ukrainian].

Hantinhton, S. P. (2006). Protystoiannia tsyvilizatsii ta zmina svitovoho poriadku [The Clash of Civilizations and the Remaking of World Order]. Lviv: Kalvariia, 472 p. [in Ukrainian].

Honcharevskyi, V. (2011). Tsyvilizatsiinyi pidkhid do istorii: Suchasnyi ukrainskyi dosvid (1991 - 2009) [Civilization Approach to the History: Contemporary Ukrainian Experience (1991 - 2009)]. Kyiv: Logos, 220 p. [in Ukrainian].

Hnatiuk, O. (2005). Proshchannia z imperiieiu: ukrainski dyskusii pro identychnist [Farewell with Empire: Ukrainian discussions on identity]. Kyiv: Krytyka, 528 p. [in Ukrainian].

Hrybovskyi, V. (2010/2011). Hytrist heohrafichnoho rozumu [The trick of the geographic mind]. Eidos. Almanah teorii ta istorii istorychnoi nauky, 5, 510-526 [in Ukrainian].

Hrytsak, Ya. (2004). Nedoevropa: Zakhidni mandrivky Skhidnoiu Evropoiu [Not up to Europe : the Western travels to the Eastern Europe]. Hrytsak Ya. Strasti za natsionalizmom: Istorychni esei. (pp. 281-297). Kyiv: Krytyka [in Ukrainian].

Hrytsak, Ya. (2011). Ukraina mizh Skhodom i Zakhodom: stara istoriia na novyi lad [Ukraine between the East and the West: the old history in a new way]. Hrytsak Ya. Strasti za natsionalizmom. Stara istoriia na novyi lad. (pp. 279-297). Kyiv: Krytyka [in Ukrainian].

Dashkevych, Ya. (1991). Ukraina na mezhi mizh Skhodom i Zakhodom (XIV -XVIII st.) [Ukraine on the border between the East and the West (XIVth - XVIIIth century)]. Zapysky Naukovoho tovarystva im. T. Shevchenka: Pratsi istoryko-filosofskoi sektsii, CCXXII, 28-44 [in Ukrainian]. 
Kolesnyk, I. (2013). Dvokulturnist yak fenomen dukhovnoho svitu ukraintsiv [Biculturalism as a phenomenon of the spiritual world of the Ukrainians]. Historia - Mentalność - Tożsamość. Rosja i Europa Zachodnia w polskiej i ukraińskiej historiografii XIX i XX wieku. (pp. 94-110). Gdańsk: Wydawnictwo Uniwersytetu Gdańskiego. URL: http://lib.npu.edu.ua/cgi-bin/irbis64r/cgiirbis_64. exe? $\mathrm{LNG}=\& Z 21 \mathrm{ID}=\& \mathrm{I} 21 \mathrm{DBN}=\mathrm{KST}$ PRINT $\& \mathrm{P} 21 \mathrm{DBN}=\mathrm{KST} \& \mathrm{~S} 21 \mathrm{STN}=1 \& \mathrm{~S} 21 \mathrm{REF}=\& \mathrm{~S} 21 \mathrm{~F}$ $\mathrm{MT}=$ fullw_print $\& \mathrm{C} 21 \mathrm{COM}=\mathrm{S} \& \mathrm{~S} 21 \overline{\mathrm{CNR}}=\& \mathrm{~S} 21 \mathrm{P} 01=0 \& \mathrm{~S} 21 \mathrm{P} 02=0 \& \mathrm{~S} 21 \mathrm{P} 03=\mathrm{M}=\& \mathrm{~S} 21 \mathrm{STR}=$ [in Ukrainian].

Kolesnyk, I. (2012). Mentalne kartohrafuvannia ta profesiia istoryka: mizh ratsionalnym $\mathrm{y}$ uiavlenym [Mental mapping and the profession of the historian: between the rational and the imaginable]. Ukrainskyi istorychnyi zhurnal, 5, 135-156 [in Ukrainian].

Kondakov, Y. V., Sokolov, K. B. \& Khrenov, N. A. (2011). Tsivilizatsyonnaia identychnost $v$ perekhodnuiu epokhu: kulturolohycheskyi, sotsyolohycheskyi y iskusstvovedcheskyi aspekty [Civilizational identity in a transitional era: the cultural, the sociological and the art history aspects]. Moskva: Progress-Tradytsyia, 1024 p. [in Russian].

Kost, S. (2004). Mizh Skhodom i Zakhodom (Problema istorychnoi oriientatsii na storinkah zahidnoukrainskoi presy pershoi polovyny XX st.) [Between the East and the West (The problem of historical orientation on the pages of the Western Ukrainian press of the first half of the XXth century)]. Visnyk Lvivskoho universytetu. Seriia: zhurnalistyka, 25, 260-273 [in Ukrainian].

Krymskyi, S. B. \& Pavlenko, Yu. B. (2007). Tsyvilizatsiinyi rozvytok liudstva [Humanity Civilizational Development]. Kyiv: Feniks, 216 p. [in Ukrainian].

Lysiak-Rudnytskyi, I. (1994). Ukraina mizh Skhodom i Zakhodom [Ukraine between the East and the West]. Lysiak-Rudnytskyi I. Istorychni ese. Vol. 1. (pp. 1-9). Kyiv: Osnovy [in Ukrainian].

Masnenko, V. (2013). Ukraina, Polshcha, Rosiia u systemi tsyvilizatsiinyh koordynat: viziia Viacheslava Lypynskoho [Ukraine, Poland, Russia in the system of civilizational coordinates: Vyacheslav Lypynskyi's vision]. Historia - Mentalność - Tożsamość. Rosja i Europa Zachodnia w polskiej i ukraińskiej historiografii XIX i XX wieku. (pp. 307-323). Gdańsk: Wydawnictwo Uniwersytetu Gdańskiego [in Ukrainian].

Okinshevych, L. (2011). Mizh Skhodom i Zakhodom [Between the East and the West]. Ukrainska istoriosofiia (XIX - XX st.): antologiia. (pp. 189-195). Sumy: Sumskyi derzhavnyi universytet [in Ukrainian].

Telvak, V. (2013). Rosiia ta Yevropa v istoriosofskomu dyskursi y istoriohrafichnii praktytsi Mykhaila Hrushevskoho [Russia and Europe in Mykhailo Hrushevskyi's historiosophical discourse and the historiographic practice]. Historia-Mentalność-Tożsamość. Rosja i Europa Zachodnia w polskiej i ukraińskiej historiografii XIX i XX wieku. (pp. 298-306). Gdańsk: Wydawnictwo Uniwersytetu Gdańskiego [in Ukrainian].

Shevchenko, I. (2001). Ukraina mizh Skhodom i Zakhodom. Narysy z istorii kultury do pochatku XVIII stolittia [Ukraine between the East and the West. The history of culture essays to the beginning of the XVIIIth century]. Lviv: Instytut Istorii Tserkvy Lvivskoi Bohoslovskoi Akademii, $250 \mathrm{p}$. [in Ukrainian].

Yakovenko, N. (2002). «Ukraina mizh Skhodom i Zakhodom»: proektsiia odniiei idei [«Ukraine between the East and the West»: one idea projection]. Yakovenko N. Paralelnyi svit. Doslidzhennia z istorii uiavlen ta idei v Ukraini XVI-XVII st. (pp. 333-365). Kyiv: Krytyka [in Ukrainian].

The article was received on April 22, 2019. Article recommended for publishing 10/06/2019. 